\title{
PERSONALITY, UNILATERALISM, OR BULLYING: WHAT CAUSED THE END OF THE COLD WAR?
}

\author{
GERALD SCHNEIDER \\ Graduate Institute of International Studies \\ 1211 Geneva 21 \\ Switzerland \\ and \\ THOMAS WIDMER and DIETER RULOFF \\ Universität Zürich \\ Forschungsstelle für Politische Wissenschaft \\ 8008 Zürich \\ Switzerland \\ (Received for Publication October 20, 1992)
}

\begin{abstract}
This study evaluates the controversy about the importance duly attributed to domestic and international sources of the end of the Cold War. Our quasi-experimental research supports the hypothesis that Gorbachev's accession to power was largely responsible for the historic improvement in the relationship between the United States and the Soviet Union. The leadership change also enabled the Soviets to pursue unilateral initiatives although conflictual behavior supplanted the effect of such GRIT measures. The coercive diplomacy of the United States in the 1980 s seems to have contributed to the moderation of Soviet foreign policy to a lesser extent. The Box-Tiao models focus on the period between 1948 and 1989 and rely on an updated version of the Conflict and Peace Data Bank (COPDAB).
\end{abstract}

KEYWORDS: foreign policy change, U.S. soviet relations, intervention analysis, ARIMA models, events data, quasi-experiments

In the light of the everlasting longing for courageous leadership, the Nobel Committee chose a very popular line of argument on October 15,1990 . Justifying the first, and most likely the last, Peace Award to a communist head of state, it hailed Mikhail Gorbachev for his "many and decisive contributions to East-West relations" (Facts on File, 1990, p. 787).

The "Gorby-effect" has gained popular support in the Western media and among some scholars since the mid-eighties. Among the innumerable qualitative evaluations of the Soviet leader, one volume is even entitled "The Impact of Gorbachev" (Spring, 1991). According to one of the implicit hypotheses, the seizure of power by Gorbachev was concomitant with the beginning of a process which culminated in the fall of the Berlin Wall and Soviet 
recognition of the German reunification. Since the dissolution of the Soviet Union and the resignation of its President, this conviction could eventually establish itself as the most popular doctrine about the end of the Cold War: "Gorbachev will be the man who made it all possible," wrote Newsweek (December 23, 1991).

The leadership hypothesis is paralleled by the assertion that the transformation occurred later through the implementation of a cooperative Soviet approach towards arms control. The historical change, therefore, was allegedly brought about by the "New Thinking" of the decision-makers surrounding Gorbachev. In the most detailed quantitative study on the relationship between the Superpowers, Goldstein and Freeman (1990, p. 154) propose the existence of a carefully drafted game plan to alter East-West relations, and they speak of a "super-version" of Osgood's (1962, pp. 85-134) "GRIT"' (Graduated Reciprocation in Tension Reduction).

On a theoretical level, both conjectures reflect the assumption that domestic politics are major determinants of the interactions between states. Hence, both of them borrow from a cornerstone of liberal reasoning. In spite of this parallelism, nonetheless, they differ about how and when the transformation of the U.S.-Soviet foreign policy occurred. According to the first interpretation, the shift should have taken place immediately or shortly after Gorbachev succeeded Chernenko as Secretary General in March 1985. The proponents of the second view argue that the most significant arms control proposals by the Soviets were more important than the takeover by a new politician. Furthermore, instead of a single-shot event such as a leadership change, a number of unilateral initiatives allegedly turned the U.S-Soviet relationship towards a more cooperative foreign policy.

Rooted in classical realist reasoning, a third position on the conversion of Soviet behavior towards the United States stands out against all explanations focusing on domestic sources. This rather controversial interpretation of the end of the Cold War proposes that the coercive diplomacy of the United States forced the Soviets into an accommodating position. Hence, "negotiating from strength" in general, and the arms build-up during the first Reagan administration in particular, constrained the options that were available to the Soviet leadership (Bell, 1989, p. 35, Gaddis, 1989, p. 13, Rice 1990, p. 82). Theoretically, the change in Soviet behavior would thus be a consequence of how the relationship between the two Superpowers developed prior to Perestroika and Glasnost. While not necessarily denying the effects of the ailing Soviet economy and the subsequent domestic reforms, this school of thought considers interstate forces as being primarily responsible for the change in the international environment.

Juxtaposition of these conflicting views shows that there is as yet no consensus about how the historical improvement in the relationship between the Cold War Superpowers evolved. This controversy will most likely continue as only but a few assessments until today have moved beyond the framework of descriptive reasoning.

In order to explain the change in the U.S.-Soviet diplomatic climate, the present study uses a statistical approach. Two major reasons justify this choice. Unlike qualitative studies, this perspective allows for challenging conventional wisdom about possible origins of Soviet moderation by subjecting the underlying hypotheses to rigorous testing. On the other hand, the lack of hard evidence is most likely a consequence of the scarcity of actual events data in the field of quantitative international politics. In trying to overcome the discontinuity at least for the interactions between the United States and the Soviet Union, the authors have updated the most widely used of the corresponding data sets (McGowan et al., 1988, p. 111), 
namely the Conflict and Peace Data Bank (COPDAB). ${ }^{1}$ As a result, the temporal domain of the study covers the whole Cold War period and ranges from January 1, 1948 to December, 31 1989. 2 The second reason for choosing an empirical approach is the inadequacy of formal models to capture some of the questions which are raised in this paper. Interestingly, two proponents of mathematical reasoning acknowledge the existence of this limitation. Hence, Downs and Rocke $(1990$, p. 8$)$ write that one of the central topics of our piece of research, the consequences of leadership change, cannot be easily deduced from an axiomatic model (for "Cold War Endgames" see Aggarwal and Allan, 1992).

In the following, first we will review theoretical contributions and derive some of their substantive and testable propositions. After summarizing recent research using events data and operationalizing the variables, we will describe the time series in an univariate way and, finally, we will test our model. The study concludes with a call for further examinations relying on both "slow" variables as, for instance, national capabilities and "quick" predictors as they are represented in events data. Only studies examining long-term trends can establish how much the Soviet leadership contributed to its own downfall by holding on to an inefficient economic system and by allocating too many resources to military spending.

\section{THEORETICAL INSIGHTS INTO THE END OF THE COLD WAR}

After the end of the Cold War, one of the dominant reactions of political scientists was dismay over their own (and their colleagues') inability to predict these events. Some went as far as claiming that the "separating schools of thought are also tumbling down" (Ferguson and Mansbach, 1991, p. 363). Others did not discard existing theories, but shifted their focus. Hence, change instead of stability became the crucial object of analysis.

As was the case during the East-West confrontation, most evaluations of current theories continue the habit of contrasting realist and liberal paradigms. In an exhaustive and more detailed review, Evangelista (1991, p. 288) develops twelve hypotheses about the origins of the Soviet policy reversal. Risse-Kappen (1991a) links similar explanations to different schools of thought. Among his explanatory variables, the domestic sources dominate: "Soviet hegemonic decline" (Realism); "peace through strength" (Realism); "exposure to Western values" (Liberalism); "evolutionary learning" (Regime Theory) and "elite re-coalitioning" (domestic politics and sociological institutionalism). To examine all of the related suggestions would lie beyond the scope of the present study. Furthermore, several of these factors could only be operationalized with great difficulty, ignoring the counter-evidence with regard to some of the hypotheses.

To study policy change explicitly is a departure from the focus of most quantitative studies on the relationship between the Soviet Union and the United States. Many recent studies center on the question of reciprocity (for an overview see Patchen, 1991). However, there are two major exceptions. Trying to adapt the Rational Expectations approach to the field of International Relations, McGinnis and Williams $(1989$, p. 1118) study how a one-sided policy reversal or other unforeseen exogenous events affected the Superpower rivalry. According to their results, the relationship between the Soviet Union and the United States was very robust regarding such incidents in the period from 1948 to 1978. Sharing the methodological orientation ${ }^{3}$ of McGinnis and Williams, Goldstein and Freeman (1990, pp. 74-79) simulated the effects of cooperative gestures in the Sino-Soviet-American triangle of Su- 
perpower relations. In a somewhat impressionistic way, they moreover describe the effects of six cooperative initiatives, among them the Soviet testing moratorium of 1985.

Their positive evaluation of this measure naturally leads back to the question of which factor was the more important for the transformation of the relationship between the two Superpowers-Gorbachev's rise to power, such unilateral gestures by the Soviet leadership or preceding U.S. behavior.

The Effects of Leadership change: Before Gorbachev was named Secretary General of the CPSU, the study of leadership change was already a favorite topic in the field of Soviet studies. As no consensus exists as to whether newly elected Secretaries General manipulated the economy in order to gain popular support (Bunce and Roeder, 1986), the effects of power transitions in the realm of foreign policy seem to be equally disputable. Speculating on the post-Brezhnev foreign policy, Hodnett (1981, p. 112) prudently adhered to a turn towards more cooperation as well as a more confrontational course as valid possibilities. In his view, the "unpredictable" outcome depended on the domestic distribution of power and on developments in the international environment. Some domestic trends certainly seem to have influenced Brezhnev and his successors. The role of formal leaders in foreign policymaking appears to have diminished in parallel to the growing participation of other decision-makers. In the dusk of the Brezhnev era, Bialer (1981, p. 414) could therefore discern a more consensual and institutionalized foreign policy process than in previous periods. Drawing on this observation, Mikhail Gorbachev's foreign policy reform proved itself more impressive because of the apparently successful attempt to overcome bureaucratic inertia.

The conceptual difficulties in assessing the impact of leadership change arise mostly due to the different modes of change. The first possibility is that of a sudden impact. In the setting of liberal democracies, there is often empirical evidence for a similar, though in the long run, discounted "honeymoon" or inauguration effect (Norpoth, 1984). Another likelihood is that Gorbachev could only increase his power stepwise. Consequently, the policy shift would have been brought about only in a piecemeal manner. From this point of view, Soviet policies have "strikingly" caught up with Gorbachev's consolidation of power (Brown, 1989, p. 189).

Implementation of GRIT: The change in the relationship between the United States and the Soviet Union also led to a revival of the more optimistic prescriptions for Arms Control. According to Rittberger and Züm (1991), the institutionalization of conflict management was a major pivot of the transformation in the East-West conflict. Among the more specific precepts, Osgood's famous GRIT strategy (1962), short for "Graduated Reciprocation in Tension Reduction," underwent the most significant comeback. While based on the principle of reciprocity, this approach is unilateralistic and designed to set a spiral of tension reduction into motion. GRIT starts when one side announces accommodative moves which should gradually supersede distrust by mutual confidence. Another important feature is that an initiator continues to carry out his gameplan, regardless of the immediate reaction of the other side.

While recent research on the effectiveness of different strategies of cooperation to a large extent took place in the realms of computer simulation (Axelrod, 1984, Downs and Rocke, 1990), there is historical evidence for some attempts to carry out GRIT-like policies. To mention the most famous example, Etzioni (1967) claimed that John F. Kennedy's 1963 "Strategy of Peace" was successful, because the Soviets reciprocated proportionally to the proposals by the United States, at least in the short run. More recently, Goldstein and Free- 
man (1990, p. 155) described the Soviet policy in the mid-eighties as a superversion of GRIT, though without statistically testing whether cooperative measures by the Soviets or other developments were responsible for the policy change. However, they provided an evaluation of cooperative strategies such as Tit-for-Tat and different versions of GRIT. Not surprisingly, a progressive form of GRIT which is accompanied by a steadily growing level of cooperation-PGRIT in their terminology-is the most effective of all strategies. An extended form of GRIT (EGRIT) imposes a trend towards more cooperation which lasts as long as the unilateral measures are continued (Goldstein and Freeman, 1990, p. 134). ${ }^{4}$ Comparing trigger strategies with different versions of Tit-for-Tat, Downs and Rocke (1990, pp. 142-143) derive some conditions under which cooperative gestures of great magnitude are likely to be successful. A low probability of the opponent having deadlock preferences, little noise in transmitting gestures and a long-term perspective of the leader are among these factors.

In our context, an effective GRIT strategy has to lead to a more cooperative foreign policy during the period in which the major proposals were made. As a result, the receiver should be able to distinguish the initiatives from other elements of interstate interactions, as for instance reciprocal events. In the face of uncertainty, simply to switch to cooperation is not enough. In this vein, Bendor and his collaborators have recently shown that cooperation becomes more difficult when noise is involved (Bendor, Kramer and Stout, 1991). In order to reduce the tensions between two states, a government must rely on generous instead of pure Tit-for-Tat strategies.

Two major caveats are necessary with respect to this interpretation of GRIT. First, in line with Osgood (1962, p. 95), interstate relations are only studied at an aggregate level of policy-making. This is in contrast to the wish of some observers (e.g. Rittberger and Züm, 1991) that peaceful proposals could be initiated in delimited areas of government activity. However, regime theory has not convincingly shown whether unilateral policies directly affect the overall relationship between two states or whether cooperation can start in a "bottom-up" manner in single issue areas. Lacking a clear appreciation of such spillovers, this paper considers only the first possibility. The second theoretical decision concerns itself with the question of what the ingredients of a cooperative initiative are and what the overall game plan is supposed to look like. In contrast to Goldstein and Freeman (1990), George (1988, p. 707) qualified one significant Soviet proposal, namely the moratorium on nuclear testing, as containing more conditionality than a unilateral GRIT-measure should embody. We assume that the GRIT strategy comprised of the most outstanding Soviet arms control proposals between March 1985 and December 1989. This does not necessarily imply that these steps can only be traced back to the mid-eighties. In this vein, Hudson (1990, p. 7) claims that most of Gorbachev's initiatives on national security were "merely elaborations of earlier notions along a predictable path." Such observations support the idea that the role of personality is limited. Instead of a newly selected leader, hence, other agents of change would have been pivotal for the more cooperative course of the Soviet Union vis-à-vis the United States.

In reality, it is hard to distinguish the first two hypotheses. As the leadership change could have allowed for a more cooperative policy, the two effects might have even prevailed at the same time. Furthermore, a mutual exchange between the actions of the Soviet government and the thoughts and plans of its advisors most likely took place (Zisk, 1990). The difficult temporal order also puzzles other observers. MccGwire $(1991$, p. 258) assumes that the real 
watershed in the orientation of Soviet foreign policy only evolved in the first six months of 1987.

Behavior of the United States as a driving force: As a matter of fact, the reversal of traditional precepts might not have been an act of free will. According to some observers, severe constraints forced the Soviet leadership into predominantly cooperative behavior towards the United States. Rice (1990, p. 84) argues that Gorbachev faced a limited set of options from the beginning. Instead of rejecting the challenge by the United States and continuing the arms race, the Soviet secretary-general allegedly tried to make a virtue out of Soviet weakness. As if alluding to a notion coined by the former U.S. president that it "takes two to tango," Rice writes: ".... it took Reagan's commitment to a given agenda and Soviet recognition that adaptation to it could serve Soviet goals to bring U.S.-Soviet relations to where they are today" (Rice 1990, p. 86). In a similar way, Risse-Kappen (1991b, p. 187), otherwise a sharp critic of bullying negotiation tactics, contends that the INF deployment may have helped to create a new coalition which was more favorable to arms control than the old guard.

Accordingly, it was the United States and not the Soviet Union which first altered the rules of the game. In the point of view of Gaddis (1989), the American strategy consisted of three elements: "Rebuilding self-confidence," "spooking the Soviets" and "negotiating from strength." With respect to the coercive diplomacy, Gaddis qualifies President Reagan's approach as rather innocent and distant: ".... when he spoke of the possibility that a military buildup might actually lead to reductions in strategic weapons, he appears to have meant precisely what he said" (Gaddis, 1989, p. 13).

Theoretically, coercive diplomacy is a strategy which tries to make a virtue out of firmness. It hopes to change the position of the adversary in the long run by not reciprocating cooperative moves (Leng, 1984). In order to test the alleged effect of bullying, one first has to inquire if the foreign policy of the United States vigorously and permanently shifted towards a more adverse course during President Reagan's first term. Otherwise, a shift towards more active foreign policy is a further, though weaker, indication of the intention to change interstate interactions.

Usually without circumscribing the standards of success and failure, several scholars have cast doubt upon the effectiveness of the hard-liner prescriptions on how to enforce a change in Soviet policy. In particular, the purported superiority of "negotiating from strength" especially was subjected to sharp criticism. In the eyes of Haftendorn (1988, p. 27) the United States rather than the Soviet Union had to alter its policy. Others go as far as to claim that the "crusading rhetoric and confrontational policies" (MccGwire, 1991, p. 386) were counterproductive. Judging from a comparison with earlier periods of the US-Soviet relationship, Snyder (1989, p. 20) concludes that "hard-liner" positions either encouraged proponents of retrenchment or undermined the influence of the adherents of détente.

To assess the possible importance of such a suggestion cannot be done within the limited framework of this study. In the following, we will only test three hypotheses. They can be summarized as follows:

\section{Hypothesis 1: (Personality)}

The assumption of office by Mikhail Gorbachev was the main source of change in Soviet cooperative behavior towards the United States. 


\section{Hypothesis 2: (Unilateralism)}

The implementation of the "New Thinking" in the form of a GRIT strategy was the main source of change in Soviet cooperative behavior towards the United States.

Hypothesis 3: (Bullying)

The coercive diplomacy of the United States during the early eighties induced the change in Soviet foreign policy towards the United States.

\section{NOTES ON THE RESEARCH STRATEGY AND DEFINITION OF VARIABLES}

The chosen empirical approach belongs to the category of quasi-experiments (Cook and Campbell, 1979) or, to use another label, of historical experiments (Singer, 1977). To put it more precisely, the present study follows the research design of an interrupted time series analysis. It is beyond any doubt that such quantitative historical reasoning runs into severe problems of validity. Other events besides the proposed incidents might have encouraged the Soviets to change their policy orientation. On the other hand, to examine carefully the case in question diminishes the risk of misinterpretation which is, by the way, also present in more traditional modes of reasoning.

In line with most quantitative studies on the relationship between the Soviet Union and the United States (Patchen, 1991, p. 127), events data are used as a source. Following the standard definition, an event is an occurrence which was reported in a reputable public source. The data set under examination, the Conflict and Peace Data Bank (COBDAP), originally covered events in "about 135 nation states" as reported in over 70 sources (Azar, 1980, p. 146). The temporal domain of the updated series for the interactions between the United States and the Soviet Union spans the period from the inauguration of communist regimes in Eastern Europe to their overthrow (1948-1989).

Because events data are subjected to criticism from time to time, a justification for introducing them is necessary prior to outlining the methodological approach.

Advantages and disadvantages of events data: During the last years, methodologists have repeatedly attacked both the theoretical and empirical underpinnings of events data. In the former category, King $(1989$, p. 125) provided the most devastating argument by observing that events are discrete but the statistical techniques for explaining them are designed for continuous time series. In our opinion, this discrepancy tends to grow into a problem when the number of events per time unit is small. This is the case with certain types of events as, for instance, the decisions to go to war or to form alliances. However, this problem appears not to be grave for the kind of events data that are studied here. To the contrary, the sum of these events is supposed to represent a continuous process, the diplomatic climate between two nations (Allan, 1983).

On empirical grounds, the objection that events data are very noisy and unreliable is most frequent. There are some proposals on how such inadequacies could be solved (Schrodt, 1988). In the meantime, however, only imperfect events data are available. Because these sources only allow measuring dyadic behavior at a level of aggregation shorter than a year, there exists no alternative category of data. Furthermore, Goldstein (1991, pp. 197-198) convincingly shows that noise is not necessarily a problem. For the present research, disturbances could be a problem if they prohibit the possibility of detecting a real effect. If there is 
a significant impact of certain events, it is chiefly the bias of the sources that seems troublesome.

Definition of the variables: For coding events both on the cooperative and the conflictive side, a fifteen-point scale is used for the original COPDAB as well as for the update (for details see Sloan, 1973, and Azar, 1980). As an outcome variable, Soviet net cooperation will be employed. In accordance with the definitions by other researchers (Goldstein and Freeman 1990, p. 37), this indicator captures the weighted sum of cooperative events minus the weighted sum of hostile events within the same period. The explanatory variable measuring U.S. behavior is defined in the same way. The unit of temporal aggregation is one month. ${ }^{5}$

In order to control the quality of the COPDAB update, we correlated it with the merged WEIS (World Events Interaction Survey) data which consists of the original WEIS plus the WEIS-X update. ${ }^{6}$ COPDAB and WEIS correspond to one another to about the same extent as they did in previous studies (Vincent, 1983, Goldstein and Freeman, 1990, p. 39). ${ }^{7}$

Different ways of assessing impacts: The two other explanatory factors-the effects of personality and unilateralism-are dummy variables which take on the values of 1 or 0 to denote the occurrence or non-occurrence of an event. More precisely, the leadership change is a "step input" (all values after the event are 1), whereas the other variable represents a "pulse function" which only amounts to 1 in the actual time period when an event takes place.

Theoretically, an incident like the power transition from Chernenko to Gorbachev is an intervention $\left(\mathrm{I}_{1}\right)$ which is supposed to change exogenously the course of a political process $\left(Y_{v}\right)$, beginning at moment $t$. The relationshi $i_{j}$ between innovations and a political process could be estimated with different methodologies. In this piece of research, ARIMA methods are employed to model the time series. ARIMA (AutoRegressive Integrated Moving Average) makes it possible to model a series in terms of its own past values and past errors. To put it more abstractly, this approach relies on the assumption that a time series can be conceived of as an integrated stochastic process. To employ ARMMA leads into an iterative search for an optimum model which is parsimonious and which meets certain statistical criteria.

This approach is especially well developed for the task of impact assessment (Box and Tiao, 1975, Cook and Campbell, 1979). Before estimating the impact, one must first fit an ARIMA model to the time series. This initial step is intended to transform a series into "white noise" by removing its autoregressive, integrative or moving average components. Besides the intervention component, ARIMA impact models accordingly consist of a noise component $\mathrm{N}_{\mathrm{t}}$. The following formula summarizes ARIMA impact model in a general way:

$$
Y_{t}=f\left(I_{t}\right)+N_{t}
$$

Modeling the leadership change: An intervention, in general, can take four forms: abrupt-permanent, gradual-permanent, abrupt-temporary or gradual-temporary. The "Gorby-effect", if it exists at all, should either evolve in an abrupt-permanent or in a gradual-permanent manner. The first possibility implies that Soviet net cooperation towards the United States immediately reached a new level following the leadership change. Instead of such a "ramp," there would be a systematic growth of the initial effect in the second model.

In both alternatives, the intervention allegedly took place in March 1985. Chernenko died on March 10,1985, and Gorbachev's selection as his successor took place on the next day. Because Gorbachev seems to have taken power gradually throughout the short tenure of Chernenko, earlier dates are also possible. Additionally, December 1984 will be tested as an 
intervention date. On December 17, 1984, Prime Minister Thatcher said after meeting the second-ranking official of the Soviet communist party: "I like Mr. Gorbachev-we can do business together" (Facts on File, 1984, p. 937). In November 1984, there were furthermore the first signs that the Soviets would like to retum to the negotiation table. At a meeting between Foreign Minister Gromyko and Secretary of State Shuitz two months later, the Superpowers finally retreated from the deadlock in arms control by submitting to combined negotiations.

Modeling the "GRIT"-effect: In contrast to the first hypothesis, a "GRIT-effect" would consist of various interventions. Thus, the related indicator consists of pulse inputs for all months during which the Soviets announced an important step. An appendix lists the crucial Soviet policy steps which could have made part of a long-term game plan to alter East-West relations. Among these "peace initiatives," one can find the announcement and various extensions of the nuclear testing moratorium. A policy step is considered belonging to a GRIT strategy if it is unconditional and unilateral. Furthermore, single proposals within the setting of established arms control talks are not included.

\section{EXPLAINING THE CHANGE IN THE DIPLOMATIC CLIMATE}

Assessment of the three contending hypotheses will be undertaken one by one. After presenting a brief quantitative account of the Cold War, we will model the whole time series which measures Soviet net cooperative behavior.

A quantitative history of U.S.-Soviet interactions: The timeplots show how much the net cooperative behavior of the two Superpowers towards each other changed between 1948 and 1989. A brief inspection of the Soviet series (Figure 1) seems to support the assumption that a transformation took place around the time when Mikhail Gorbachev rose to power by March 1985. During the first period of détente, Soviet net cooperation does not reach the level of the mid-eighties where cooperation begins to gain over conflict. After Gorbachev's takeover, this indicator seldom falls below zero. In the heyday of Perestroika and Glasnost, the time series reaches its peak in the month of the Geneva summit.

The relationship between the two Superpowers for a long time was dominated by an almost regular cycle of crisis and détente. Soviet cooperative behavior reached its minimum already during the Berlin crisis (Blockade of West Berlin, June 1948), two months after the communist coup in Czechoslovakia (April 1948). Only the Cuban missile crisis represents a similar negative extreme (September/October 1962). The first period of cooperation followed Stalin's death (March 1953) and was marked by some diplomatic settlements-the Korean Armistice (July 1953), the Geneva Agreements on Indochina (June 1954) and the Austrian State Treaty (May 1955). Two months later, Geneva was host to the first East-West summit since World War II (July 1955).

With the suppression of the Hungarian uprising in 1956, the Soviet policy towards the United States shifted again towards a more confrontational course. A further rapprochement in 1959 pivoted around Khrushchev's visit to the United States in September, but it could not stop the trend towards an increasingly conflictive behavior. The U-2 incident (May 1960), the erection of the Berlin Wall (August 1961) and the Soviet resumption of atmospheric nuclear testing (August 1961) were the most significant preludes to the Cuban missile crisis. Détente already appears to have been launched by the next year, with the conclusion of the Hot Line Agreement (June 1963) and the Atmospheric Test Ban Treaty (July 1963). Despite 
Net Cooperative Behavior

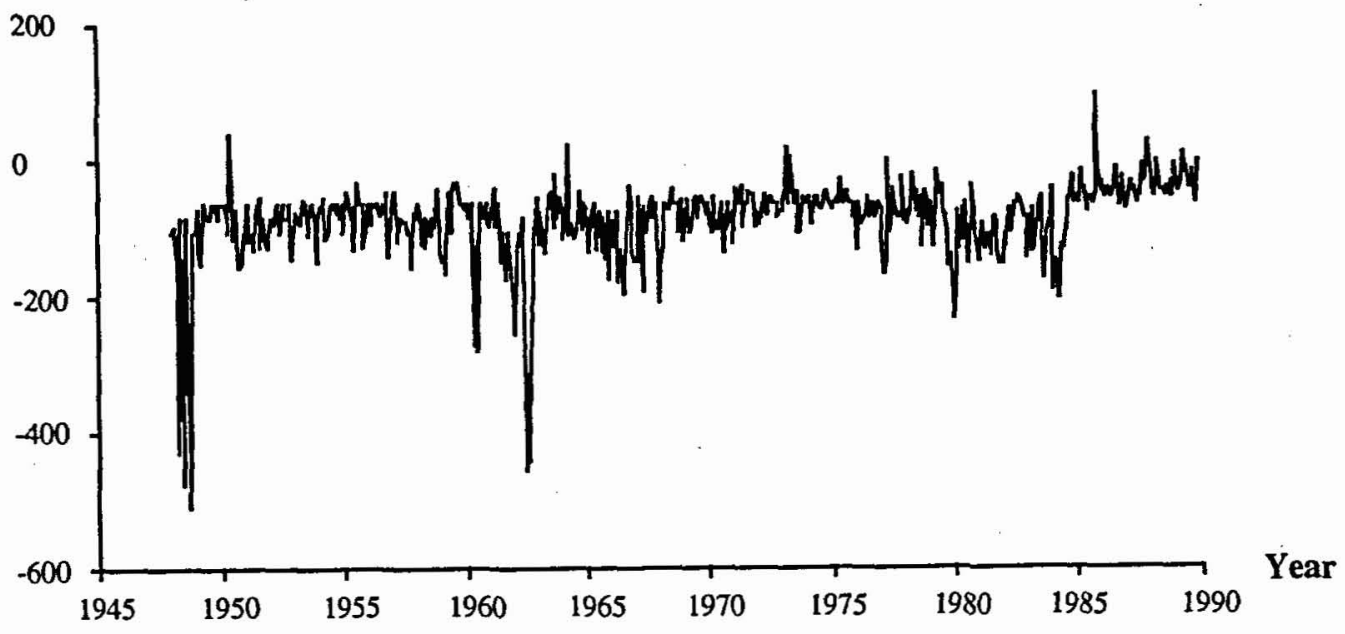

Figure 1. Soviet Net Cooperative Towards the United States (1948-89)

\section{Net Cooperative Behavior}

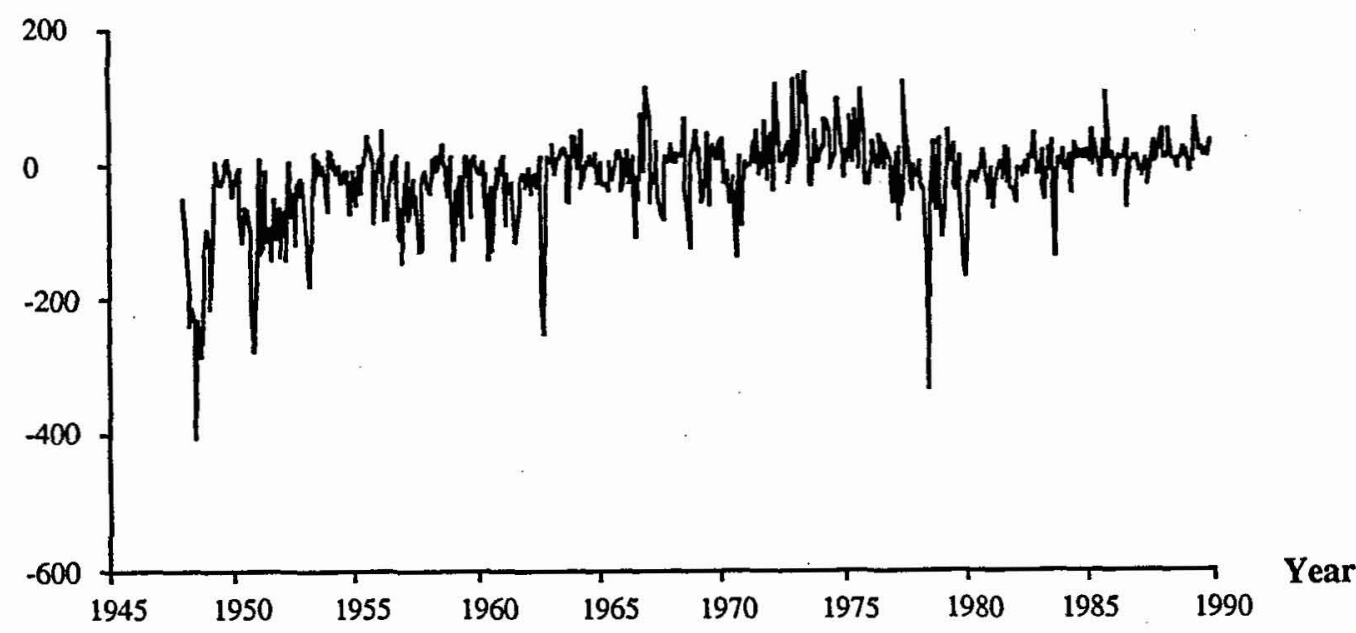

Figure 2. United States Net Cooperative Towards the Soviet Union (1948-89) 
these signals for mutual accommodation, the improvement did not last very long. The relationship even deteriorated during the Vietnam war and through the imposition of the Brezhnev Doctrine over Czechoslovakia (August 1968). Détente was marked by the conclusion of the ABM Treaty and SALT 1 (May 1972) along with a Threshold Test Ban Treaty limiting underground tests to less than 150 kilotons (July 1974). Notwithstanding these agreements, this period of moderation in the Superpower rivalry saw major crises, following the IndoPakistani-War of 1970-71 and the Yom Kippur War in October 1973.

Events in the Third World contributed to the backlash of the mid-seventies. The Final Agreement of the European Conference on Security and Cooperation (August 1975) and the signing by Carter and Brezhnev under SALT II (June 1979) could not halt the deterioration of the superpower relationship. Finally, the invasion of Afghanistan (December 1979), was followed by a major downturn in the Soviet cooperative policy. Neither this war nor the Soviet walkout from the INF (Intermediate-Range Nuclear Forces) talks in Geneva (December 1983), however, led to such hostile behavior towards the United States as was encountered in the crises of the late forties and the early sixties. This period, sometimes referred to as the Second Cold War, was also characterized by the enforcement of martial law in Poland (December 1981) and the Soviet downing of KAL-007 (September 1983). Moreover, the American boycott of the 1980 Moscow Olympics and the counter boycott of the 1984 Los Angeles Olympics by the Soviets indicated how reciprocal Superpower relations were at this time.

When Gorbachev assumed power, such petty retaliation continued. U.S. accusations that the Soviets used "spydust" to track down American diplomats in the USSR were followed by Soviet charges that its KGB officer Vitaly Yurchenko was a victim of U.S. kidnapping and assault. The arrest of the Soviet United Nations employee Gennady Zakharov as well as the American journalist Nicolas Daniloff manifested similar incidents. On the other hand, the meetings between President Reagan and Secretary General Gorbachev in Geneva (November 1985) and in Reykjavik (October 1986) led to extensive cooperation in the corresponding months, and in May 1988, President Reagan finally changed his anti-communist rhetoric at the Moscow summit (May 1988).

In March 1983, Reagan had defied the Soviet Union as a "dark, evil empire" and announced his Strategic Defense Initiative. During the two terms of the Republican President, September 1983 was the month in which U.S. behavior towards the Soviet Union was most conflictual. The invasion of Grenada (October 1983) and the deployment of Euromissiles in Great Britain and Western Germany (December 1983) were further signs of the hard-line approach by the U.S. administration. However, the series (Figure 2) was already in a depression prior to Reagan's inauguration. President Carter's stern condemnation of the Soviet intervention in Afghanistan was a precursor to Reagan's confrontational course.

Modeling the Cold War: The graphical intuition of a Gorbachev-effect can be supported statistically. The corresponding test is undertaken for the monthly data covering Soviet net cooperative behavior between 1948 and $1989(\mathrm{~N}=504)$. In the analysis of this series, univariate procedures as for instance t-tests support the impression that U.S.-Soviet relations became more stable over time. Accordingly, the variance of East-West interactions diminished, and grave crises no longer occurred as frequently or affected the process as much as in the beginning of the Cold War.

We are able to control for this systematic effect through a transfers function which includes contemporaneous U.S. behavior towards the Soviet Union as an exogeneous variable. Theoretically, the incorporation of this factor can be justified by the importance of 
reciprocity in the relationship between the Superpowers (Goldstein and Freeman, 1990, Rajmaira and Ward, 1989, and Ward and Rajmaira, 1992). In addition, the model embodies some pulse inputs. These explanatory variables were found empirically. They stand for behavior that runs counter to the overall process. Thus, they represent outlying months during which either the Soviets or the Americans unilaterally shifted their policy. Such deviations occurred during the Berlin crisis of 1948 (two months with relatively cooperative Soviet behavior), prior to the Korean war (May 1950), around the time of the Tet-offensive in the Vietnam war ${ }^{8}$ (January 1968) and twice during the term of President Carter when the U.S. administration attacked communist involvement in African Civil Wars (May 1977) and the treatment of Soviet dissidents (July 1978). These U.S. accusations are included as one input variable.

According to Table 1, Gorbachev's takeover immediately led to a change in the relationship between the Superpowers. As no significant growth factors could be obtained, we had to reject the alternative hypothesis of a gradual-permanent "Gorby"-effect. ${ }^{9}$ However, the process seemed to have been underway already before March 1985. Alternatively, when specifying December 1984 as the starting month, the effect remains significant. This model is almost as convincing as the one with its impact in March 1985. Since the parameters are very similar, both models seem to be very stable. The main measures of parsimony are Akaike's Information Criterion (AIC) and Schwartz's Bayesian Criterion (SBC). ${ }^{10}$ Substantially, the possibility of a shift towards a more cooperative foreign policy already setting in prior to Chernenko's death casts doubt upon the importance of formal leadership change, but emphasizes the role of individual personality. While Chernenko was ill, Gorbachev was indeed already acting chairperson at the Politburo and Central Committee Secretariat meetings.

In addition to the two versions of the leadership change, Table 1 furthermore shows how much Soviet net cooperative behavior was governed by reciprocity as a guiding principle. During the whole Cold War, U.S. actions greatly affected Soviet behavior. Finally, stochastic components bear a strong impact on East-West relations. The autoregressive factors underline the extent to which single events could affect the time series. A fifth-order autoregressive process was the most convincing model for the stochastic component of the model. 11

These results show that the takeover by Gorbachev and thus a domestic factor contributed to the reversal in the Soviet behavior towards the United States. It should be noted that this is the only leadership change which permanently affected Soviet net cooperative behavior towards the United States. The strong "Gorby-effect" is in stark contrast to the tests of the second hypothesis (Effects of unilateralism). Exchanging the step input function linked to the succession of the Secretary General post, we could find no significant parameters. The same happened for the combination of both domestic factors. Accordingly, the GRIT strategy did not have an additional impact on the reorientation of Soviet foreign policy subsequent to Gorbachev's rise to power.

Several reasons may explain why the unilateral initiatives by the Soviet Union did not alter its aggregate policy towards the United States. First of all, the U.S. rejection of some proposals as for instance the nuclear test moratorium urged the Soviet leaders to accuse the Reagan administration of being inflexible. Second, the principle of Tit-for-Tat also prevailed due to the growing fragmentation of the Soviet policy-making process. This internal development enabled both "hard-liners" and "soft-liners" to send their conflicting signals to 
Table 1

The Impact of Domestic Factors On Soviet Net Cooperative Behavior Towards the United States: Comparison of Two Models About the Effect of Gorbachev's Rise to Power (COPDAB 1949-1989, N=504)

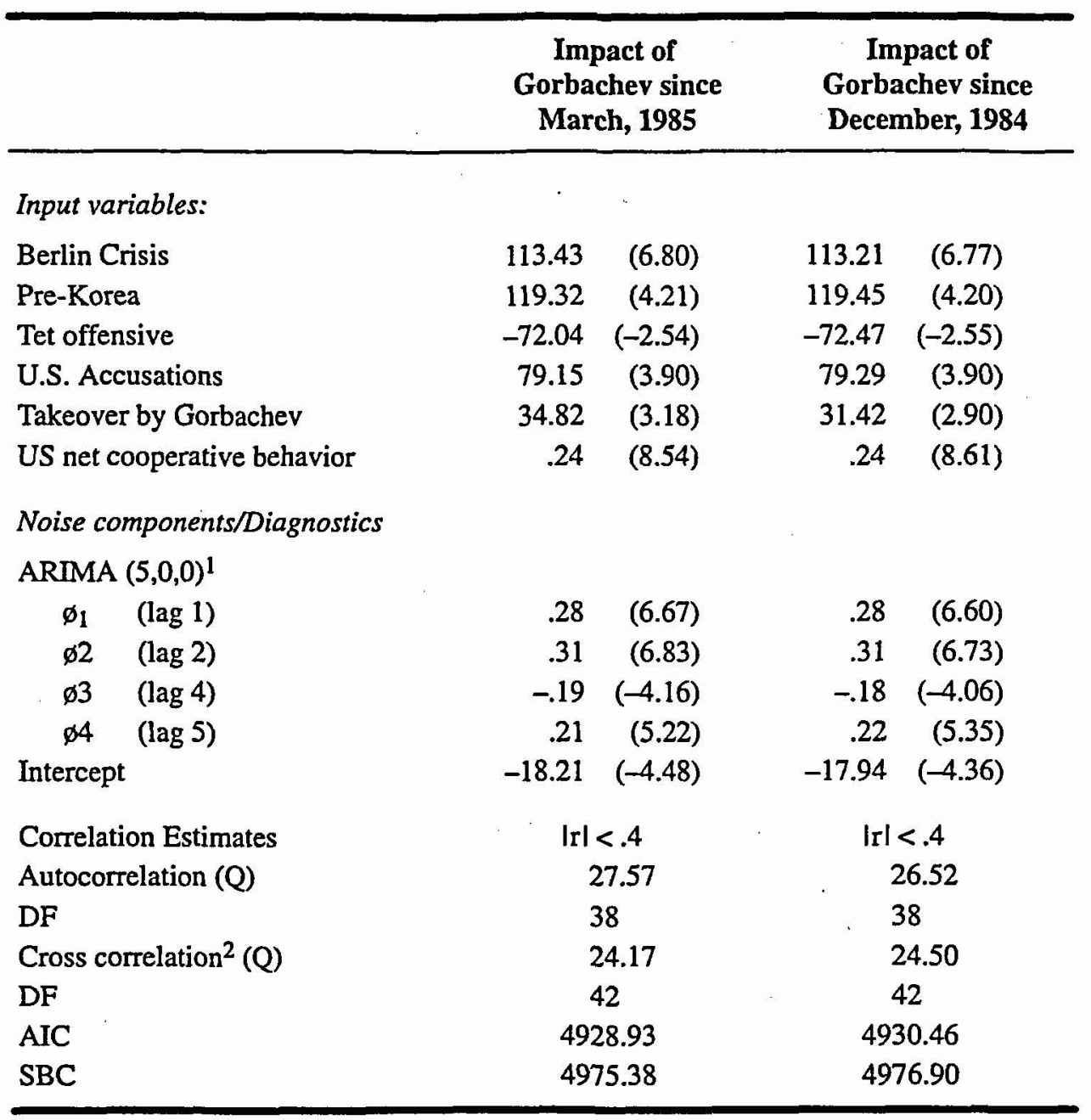

Note: The results were obtained with SAS-ETS (Maximum-likelihood estimates). t-ratios are in parentheses. ${ }^{1}$ The autoregressive factor at lag 3 is zero.

${ }^{2}$ Crosscorrelation of the residuals with the explanatory variable U.S. net cooperative behavior. 
the government of the United States. It must be acknowledged that the lack of effect could also be a consequence of how little tacit bargaining counts in the COPDAB coding scheme. The absence of a clear impact of the GRIT strategy just confirms how much generosity it takes to force interstate interactions into a more peaceful direction. Finally, the statistical techniques cannot establish whether the Soviets tried to carry out a long-term peace plan in vain or whether they were only "muddling through" with good intentions. According to some observers, no grand scheme existed at the top of Soviet leadership: "...it is not surprising that Gorbachev's defense agenda has emerged piecemeal rather than as a single master blueprint", wrote Meyer (1988, p. 128).

In order to test the third hypothesis, we have to show whether U.S. foreign policy towards the Soviet Union indeed took a more conflictive course following Ronald Reagan's inauguration. However, similar to the testing of the GRIT strategy, no significant effect of this leadership succession can be found in the analysis of U.S. net cooperative behavior, not even after reducing the input variable to a pulse function for one single month (January 1981). Accordingly, it was not only the Republican President's rhetoric and the arms buildup launched by his administration which led to a more confrontational U.S. foreign policy. The major downturn came earlier, through the change by President Carter towards a more conflictive position in the second half of his term.

On the other hand, the election of a Republican president with a pronounced anti-communist agenda could have manifested itself in yet another way with respect to current Superpower interactions. Hence, the patterns of reciprocity may have changed under Reagan from a reactive to an active policy. This possibility is tested by comparing how much contemporaneous and lagged U.S. actions influenced Soviet net cooperative behavior during the different presidencies covered by the extended COPDAB series (with the exception of George Bush's first twelve months). For all eight periods under consideration, both contemporaneous and lagged (one month) U.S. behavior were included. Due to a lack of cases, no complete ARIMA models could be built for all series. However, at least the serial autoregressive patterns which influence the series will be controlled.

The results presented in Table 2 show that the Reagan administration to a large extent set the agenda, although Soviet net cooperative behavior continued to be autoregressive. The contemporaneous and the lagged U.S. actions had a considerable influence on Soviet behavior, at least when both terms are analyzed. This relationship is in contrast to previous periods during which only current interactions had an impact. Accordingly, U.S. firmness may have forced the Soviets to keep more intensively track of U.S. moves than in previous periods.

This also reiterates the degree to which this decade was governed by reciprocity. However, whether the policy of the Reagan administration stimulated the Soviets towards increasing cooperation remains dubious. The statistical procedures only revealed that the link between U.S. and Soviet behavior was stronger throughout the eighties than in the seventies, but they could not establish any kind of causal link. On the contrary, the significance of the "Gorby-effect" stresses that there is no monocausal explanation of Soviet moderation: "Negotiation from strength is not an automatic mechanism that functions independently from the internal politics on each side," writes Evangelista (1991, p. 340) in this respect. 
Table 2

The Impact of U.S. Net Cooperative Behavior On Soviet Net Cooperative Behavior During the Cold War Presidencies (COPDAB 1948-1989, Regressions Corrected for First-order Autocorrelation)

\begin{tabular}{|c|c|c|c|c|}
\hline & $\begin{array}{c}\text { Truman } \\
(1 / 48-12 / 52)\end{array}$ & $\begin{array}{l}\text { Eisenhower } \\
(1 / 53-12 / 60)\end{array}$ & $\begin{array}{c}\text { Kennedy } \\
(1 / 61-11 / 63)\end{array}$ & $\begin{array}{c}\text { Johnson } \\
(12 / 63-12 / 68)\end{array}$ \\
\hline Constant & $\begin{array}{l}16.41 \\
(1.98)\end{array}$ & $\begin{array}{c}-8.75 \\
(-2.06)\end{array}$ & $\begin{array}{l}-39.76 \\
(-1.93)\end{array}$ & $\begin{array}{c}-28.38 \\
(-5.55)\end{array}$ \\
\hline \multicolumn{5}{|l|}{ US behavior } \\
\hline$t$ & $\begin{array}{c}0.56 \\
(8.57)\end{array}$ & $\begin{array}{c}0.25 \\
(4.10)\end{array}$ & $\begin{array}{c}0.39 \\
(1.86)\end{array}$ & $\begin{array}{c}0.03 \\
(0.27)\end{array}$ \\
\hline$t-1$ & - & - & - & - \\
\hline \multicolumn{5}{|l|}{ Autoregression } \\
\hline $\operatorname{AR}(1)$ & $\begin{array}{c}-0.33 \\
(-2.60)\end{array}$ & $\begin{array}{c}-0.24 \\
(-2.42)\end{array}$ & $\begin{array}{c}-0.48 \\
(-2.90)\end{array}$ & $\begin{array}{c}-0.22 \\
(1.71)\end{array}$ \\
\hline$N$ & 60 & 96 & 35 & 61 \\
\hline R-Square ${ }^{l}$ & 0.47 & 0.18 & 0.37 & 0.05 \\
\hline Reg. R-Square 2 & 0.57 & 0.15 & 0.11 & 0.00 \\
\hline $\mathrm{AIC}$ & 646.72 & 911.12 & 390.65 & 584.12 \\
\hline \multirow[t]{2}{*}{$\mathrm{SBC}$} & 653.00 & 918.81 & 395.32 & 590.40 \\
\hline & $\begin{array}{c}\text { Nixon } \\
(1 / 69-8 / 74)\end{array}$ & $\begin{array}{c}\text { Ford } \\
(9 / 74-12 / 76)\end{array}$ & $\begin{array}{c}\text { Carter } \\
(1 / 77-12 / 80)\end{array}$ & $\begin{array}{c}\text { Reagan } \\
(1 / 81-12 / 88)\end{array}$ \\
\hline Constant & $\begin{array}{l}-7.72 \\
(-4.17)\end{array}$ & $\begin{array}{c}-6.01 \\
(-2.65)\end{array}$ & $\begin{array}{l}-13.83 \\
(-2.06)\end{array}$ & $\begin{array}{c}-6.52 \\
(-1.17)\end{array}$ \\
\hline \multicolumn{5}{|l|}{ US behavior } \\
\hline $\mathrm{t}$ & $\begin{array}{c}0.19 \\
(4.68)\end{array}$ & $\begin{array}{c}0.19 \\
(2.89)\end{array}$ & $\begin{array}{c}0.11 \\
(1.58)\end{array}$ & $\begin{array}{c}0.46 \\
(5.10)\end{array}$ \\
\hline$t-1$ & - & - & - & $\begin{array}{c}0.21 \\
(2.40)\end{array}$ \\
\hline \multicolumn{5}{|l|}{ Autoregression } \\
\hline $\operatorname{AR}(1)$ & $\begin{array}{c}-0.16 \\
(-1.25)\end{array}$ & $\begin{array}{c}0.37 \\
(1.88)\end{array}$ & $\begin{array}{c}-0.25 \\
(-1.71)\end{array}$ & $\begin{array}{c}-0.56 \\
(-6.18)\end{array}$ \\
\hline $\mathbf{N}$ & 68 & 28 & 48 & 96 \\
\hline R-Square ${ }^{1}$ & 0.23 & 0.15 & 0.12 & 0.55 \\
\hline Reg. R-Square 2 & 0.26 & 0.28 & 0.05 & 0.23 \\
\hline AIC & 580.77 & 226.55 & 475.20 & 881.50 \\
\hline SBC & 587.43 & 230.55 & 480.82 & 891.72 \\
\hline
\end{tabular}

Note: The results were obtained with SAS-ETS (Maximum-likelihood estimates). t-ratios are in parentheses. ${ }^{1}$ This measure evaluates the prediction of the next values. It employs the structural part of the model and the past values of the residuals.

${ }^{2}$ This is the R-Square for the transformed regression. 


\section{THE LIMITS OF COERCIVE DIPLOMACY IN INDUCING DOMESTIC CHANGE}

The present article has shown that an abrupt and permanent change in the Soviet policy towards the United States accompanied the leadership change to Gorbachev. The analysis of the COPDAB events data, however, does not support they hypothesis that the Soviets consciously carried out a GRIT strategy in order to reduce the tensions between East and West. Their unilateral initiatives were still too weak to rise above the Tit-for-Tat patterns that dominated the interactions between the Cold War Superpowers even after 1985. In this perspective, it is hardly surprising that it took further exogenous developments-the revolutions in Eastern Europe and the failure of the coup-to bring the traditional East-West rivalry to its end and the Soviet Union to its dissolution.

Until the breakup of the communist empire, reciprocity thus continued to dominate the interactions of the Cold War Superpowers, though at a higher level of cooperation and less volatile with regard to single crises than in the period prior to Gorbachev. Also at the full bloom of "New thinking," the whole time series measuring Soviet net cooperative behavior is positively linked to the corresponding series for U.S. behavior. As a consequence, the change in Soviet policy cannot be explained by domestic factors only. On the other hand, it remains ambiguous exactly how much coercive diplomacy by the United States induced the Soviet policy reversal. The emergence of pronounced anti-communism in the wake of President Reagan's inauguration seems to accentuate what had already been under way since President Carter opted for a more adverse position in the second half of his term. However, it is perhaps the persistence in actively dealing with the other side which contributed to convincing the Soviets of the firm Western stand. In this sense, "negotiating from strength" appears to have been effective. Following this line of argument, the U.S. approach could only become successful if the Soviets unilaterally changed to a more cooperative course. There was no necessity for the Soviet Union to take such an unequivocally cooperative stance. On the contrary, somebody entirely different could have been elected in 1985 (Brown, 1989, pp. 180-185). Considering the possibility of prolonged rivalry, the risks inherent in coercive diplomacy are evidently tremendous. At least with regard to the historical record, it is very fortunate that the losing Superpower disintegrated without launching a last battle against its major antagonist (Kennedy, 1987).

Like many other issues linked to the "Gorby"-effect, the likelihood of such a reconciliation must be seen in a comparative light. Given the dramatic redefinition of the political landscape, there is accordingly a growing need to study the causes and implications of systemic change. As this study had the short-term determinants of East-West relations as its sole focus, some plausible long-term explanations for the Gorbachev phenomenon still await rigorous inquiry.

\section{APPENDIX: Soviet "GRIT-Proposals 12}

- April 7, 1985: Moratorium on the deployment of Soviet intermediate range missiles in Europe

- April 17, 1985: Soviets seem willing to suspend testing of nuclear weapons

- May 17, 1985: Gorbachev repeats A test ban offer

- July 29, 1985: Soviet Union suspends A tests 
- August 13, 1985: Gorbachev offers A test freeze

- January 15, 1986: Announcement of a gradual elimination of nuclear weapons, leading to complete nuclear disarmament by the year 2000

- February 20, 1986: Gorbachev indicates USSR readiness to accept on-site inspection to verify a nuclear test ban

- February 10, 1986: Extension of nuclear test moratorium

- March 13, 1986: USSR announces it will extend its nuclear test moratorium, until U.S. carries out another test

- April 18, 1986: Proposal for widening scope of conventional force reduction efforts

- May 14, 1986: Further extension of moratorium on nuclear tests

- August 18, 1986: USSR extends nuclear test moratorium

- February 28, 1987: Initiative to lead separate negotiations on medium-range missiles

- April 10, 1987: Gorbachev suggests immediate separate talks on short-range nuclear weapons in Europe and announces that USSR has stopped manufacturing chemical weapons

- September 16, 1987: Gorbachev calls for creation of body under UN auspices to monitor compliance with arms control accord

- January 18, 1988: Shevardnadze suggests removal of all tactical nuclear weapons in Europe as well as significant cuts in conventional arms

- February 25, 1988: USSR begins withdrawal of SS-12 missiles prior to INF treaty ratification

- March 16, 1988: Gorbachev steps forward with proposal to freeze the number of Superpower warships in the Mediterranean

- December 7, 1988: Gorbachev announces unilateral cuts in Soviet conventional forces in Europe

- January 7, 1989: USSR claims that it will unilaterally destroy its chemical weapons

- April 7, 1989: USSR claims to cease production of weapons-grade uranium in 1989

\section{ACKNOWLEDGMENTS}

The present study is part of the Zürich project on East-West relations (Frei and Ruloff, 1983, 1988). It was written during a post-doctoral stay of Gerald Schneider at the University of Michigan (Ann Arbor). An earlier version was presented under the title "Gorby, Grit, or Rambo: A Quantitative Appraisal of the End of the Cold War" at the 1992 ISA convention in Atlanta, Georgia. The authors gratefully acknowledge the benefits received from comments by Lars-Erik Cederman, Matthew Evangelista, Ted Hopf, Simon Hug, Paul Huth, Pat James, J. David Singer, Erich Weede and the reviewers of this journal.

\section{NOTES}

1. This situation is likely to improve in the near future. As these lines are written, researchers at the University of Maryland have started to generate the Global Event-Data System (GEDS). Furthermore, there are several inconclusive updates, including our own, already available-Goldstein and Freeman's WEIS-X (see Goldstein 1991 for a description) and another COPDAB version which was collected at the University of Colorado, Boulder. The Colorado data set differs from ours because it is a translation of the World Events Interaction Survey (WEIS) update into the COPDAB coding scheme. 
2. The coding of new data was done by Gerald Schneider (1979-1984), Dieter Ruloff (1984-1986) and Urs Schaffner (1986-1989) and recoded for the entire period by both Dieter Ruloff and Gerald Schneider. The coding rules were the same as in the original COPDAB which consists of dyadic events between 1948 and 1978. The New York Times Index and Keesing's Contemporary Archives were the sources for the current update.

3. Goldstein and Freeman employ Vector Autoregression (VAR) as a research tool, whereas McGinnis and Williams partly use the more restrictive Bayesian Vector Autoregression approach. For a discussion of the application of VAR to Political Science see Freeman, Williams and Lin (1989).

4. For a quantitative study see James and Harvey (1992).

5. This level of aggregation is a compromise between possible levels of aggregation. For a comparison of the adequacy of different units see Goldstein (1991, p. 198).

6. WEIS covers the period 1966 to 1986 . Goldstein and Freeman extended this data set to June 1989. Due to changes in coding and sources, Goldstein (1991) examines the update separately.

7. The Pearson correlation coefficients for the monthly aggregates for the period between January 1,1979 and June 30,1989, are the following (in parenthesis the corresponding values for the period between January 1, 1966 and June 30, 1989): Soviet net cooperation (COPDAB)/Soviet net cooperation (WEIS) 0.52 (0.45); U.S. net cooperation (COPDAB)/U.S. net cooperation (WEIS) $0.61(0.48)$.

8. On January $22-231968$, North Korean patrol boats also seized the U.S. electronic intelligence ship Pueblo.

9. The most convincing model of such a gradual-permanent effect showed patterns of oscillation for the intervention taking place in March, 1985. It could be accepted as a model only under the condition that contemporaneous U.S. behavior is excluded as an explanatory variable. The overall impact which stabilized eight months after Gorbachev's accession to power was slightly more moderate than the effect of the abrupt-permanent model reported in table 1.

10. Similar to related standards, these criteria consist of the sum of the log-transformed estimate of the error variance and a penalty which correlates with the number of parameters of a model. The criteria differ in the extent of the penalty. The parsimony of the models is also expressed in the small correlations between the estimates. Finally, the Ljung-Box Q-statistic is a "portmanteau" test which measures whether the residuals are correlated with each other or with an explanatory variable.

11. The autoregressive factor at lag 3 is zero and thus not included in Table 1.

12. The sources for the selection were MccGwire (1991), Keesing's Contemporary Archives, various issues of the SIPRI yearbook as well as of the IISS strategic survey.

\section{REFERENCES}

Aggarwal, Vinod K. and Pierre Allan. "Cold War Endgames" in Pierre Allan and Kjell Goldmann (eds.). The End of the Cold War. Dordrecht, Martinus Nijhoff 1992.

Allan, Pierre. Crisis Bargaining and the Arms Race. A Theoretical Model. Cambridge, Mass.: Ballinger, 1983. Axelrod, Robert. The Evolution of Cooperation. New York: Basic Books, 1984.

Azar, Edward E. "The Conflict and Peace Data Bank (COPDAB) Project." Journal of Conflict Resolution, Vol. 24 (1980), pp. 143-152.

Bell, Coral. The Reagan Paradox. American Foreign Policy in the 1980s. Aldershot: Edward Elgar, 1989.

Bendor, Jonathan; Roderick M. Kramer, and Suzanne Stout. "Cooperation in a Noisy Prisoner's Dilemma." Journal of Conflict Resolution, Vol. 35 (1991), pp. 691-719.

Bialer, Seweryn (ed.). The Domestic Context of Soviet Foreign Policy. Boulder, CO: Westview Press, 1981.

Box, George E.P. and Gwilym M. Jenkins. Time Series Analysis: Forecasting and Control. San Francisco: Holden Day, 1976 (2nd edition).

Box, George E. P. and George C. Tiao. "Intervention Analysis with Applications to Economic and Environmental Problems." Journal of the American Statistical Association, Vol. 70 (1975), pp. 70-79.

Brown, Archie. "Power and Policy in a Time of Leadership Transition." pp. 163-217 in Archie Brown (ed.) Political Leadership in the Soviet Union. London: Macmillan, 1989.

Bunce, Valerie and Philip G. Roeder. "The Effects of Leadership Succession in the Soviet Union." American Political Science Review Vol. 81 (1986), pp. 215-224.

Cook, Thomas D. and Donald T. Campbell. Design and Analysis. Issues for Field Settings. Boston: Houghton Mifflin Company, 1979. 
Downs, George W. and David M. Rocke. Arms Races and Cooperation. Tacit Bargaining, Arms Races, and Arms Control. Ann Arbor: University of Michigan Press, 1990.

Etzioni, Amitai. "The Kennedy Experiment." Western Political Quarterly, Vol. 20 (1967), pp. 361-380.

Evangelista, Matthew. "Sources of Moderation in Soviet Security Policy." pp. 255-354 in Philip E. Tetlock et al. (eds.) Behavior, Society, and Nuclear War (Volume 2), New York: Oxford University Press 1991.

Ferguson, Yale H. and Richard W. Mansbach. "Between Celebration and Despair: Constructive Suggestions for Future Intemational Theory." International Studies Quarterly, Vol. 35 (1991), pp. 363-386.

Freeman, John R., John T. Williams and Tse-Min Lin. "Vector Autoregression and the Study of Politics." American Journal of Political Science, Vol. 33 (1989):842-877.

Freeman, John R. and Joshua S. Goldstein. "U.S.-Soviet-Chinese Relations: Routine, Reciprocity, or Rational Expectations." American Political Science Review, Vol. 85 (1991), pp. 17-35.

Frei, Daniel and Dieter Ruloff. East-West Relations. Cambridge, Mass.: Oelgeschlager, Gunn, and Hain, 1983.

Frei, Daniel and Dieter Ruloff. "Reassessing East-West Relations: A Macroquantitative Analysis of Trends, Premises and Consequences of East-West Cooperation and Conflict." Intemational Interactions, Vol. 15 (1988), pp. 1-23.

Gaddis, John Lewis. "Hanging Though Paid Off." Bulletin of the Atomic Scientist, Vol. 45 (1989), pp. 11-14.

George, Alexander L. "Strategies for Facilitating Cooperation." pp. 692-711 in Alexander L. George, Philip L. Farley and Alexander Dallin (eds.). U.S.-Soviet Security Cooperation. New York/Oxford: Oxford University Press, 1988.

Goldstein, Joshua S. "Reciprocity in Superpower Relations: An Empirical Analysis." International Studies Quarterly, Vol. 35 (1991), pp. 195-209.

Goldstein, Joshua S. and John R. Freeman. Three-Way Street. Strategic Reciprocity in World Politics. Chicago and London: University of Chicago Press 1990.

Haftendorn, Helga. "Toward a Reconstruction of American Strength: A New Era in the Claim to Global Leadership." pp. 3-29 in Helga Haftendorn and Jacob Schissler (eds.) The Reagan Administration: A Reconstruction of American Strength? Berlin/New York: Walter de Gruyter, 1988.

Hodnett, Grey. "The Pattern of Leadership Politics." pp. 87-118 in Seweryn Bialer (ed.) The Domestic Context of Soviet Foreign Policy. Boulder, CO: Westview Press, 1981.

Hudson, George E. Soviet National Security Policy under Perestroika. Boston: Uwin Hyman, 1990.

James, Patrick and Frank Harvey. "The Most Dangerous Game: Superpower Rivalry in International Crises, 1948-1985." Journal of Politics, Vol. 54 (1992), pp. 25-53.

Kennedy, Paul. The Rise and Fall of the Great Powers. New York: Random House, 1987.

King, Gary. "Event Count Models in International Relations." International Studies Quarterly, Vol. 33 (1989), pp. 123-148.

Leng, Russell J. "Reagan and the Russians: Crisis Bargaining Beliefs and the Historical Record." American Political Science Review Vol. 78 (1984), pp. 338-335.

McGowan, Pat, Harvey Star, Gretchen Hower, Richard L. Merritt and Dina A. Zinnes. "International Data as a National Resource." International Interactions, Vol. 14 (1988), pp. 101-113.

McGinnis, Michael D. and Williams, John D. "Change and Stability in Superpower Rivalry." American Political Science Review, Vol. 83 (1989), pp. 1101-1123.

MccGwire, Michael. Perestroika and Soviet National Security. Washington, D.C.: Brookings, 1991.

Meyer, Stephen M. "The Sources and Prospects of Gorbachev's New Political Thinking on Security." International Security, Vol. 13 (1988), pp. 124-163.

Norpoth, Helmuth. "Economics, Politics, and the Cycle of Presidential Popularity." Political Behaviour Vol. 6 (1984), pp. 253-273.

Osgood, Charles E. An Alternative to War or Surrender. Urbana: University of Illinois Press, 1962.

Patchen, Martin. "Conflict and Cooperation in American-Soviet Relations: What have we Learned from Quantitative Research." International Interactions, Vol. 17 (1991), pp. 127-143.

Rajmaira, Sheen and Michael D. Ward. "Evolving Foreign Policy Norms: Reciprocity in the Superpower Triad." International Studies Quarterly, Vol. 34 (1989), pp. 457-476.

Rice, Condoleezza. "U.S.-Soviet Relations." pp.71-89 in Berman, Larry (ed.) Looking Back on the Reagan Presidency. Baltimore and London: Johns Hopkins University Press, 1990.

Risse-Kappen, Thomas. "The End of the Cold War and Theories of Change in International Relations." Paper presented at the meeting of the European Consortium for Political Research, Essex, England, March 22-28, 1991a. 
Risse-Kappen, Thomas. "Did 'Peace through Strength' End the Cold War?" International Security Vol. 16 (1991b), pp. 162-188.

Rittberger, Volker and Michael Zürn. "Transformation der Konflikte in den Ost-West-Beziehungen. Versuch einer institutionalistischen Bestandesaufnahme." Politische Vierteljahresschrift, Vol. 32 (1991), pp. $399-424$.

Schrodt, Philip A. "The Statistical Characteristics of Events Data." Paper presented at the meeting of the International Studies Association, St. Louis, Missouri, 1988.

Singer, J. David. "The Historical Experiment as a Research Strategy in the Study of World Politics." Social Science History, Vol. 2 (1977), pp. 1-22.

Sloan, Thomas J. "Conflict and Peace Data Bank (COBDAB): A Manual for Users of the Descriptive and Analytic Events Data." Studies of Conflict and Peace, Report No. 12, University of North Carolina, Chapel Hill 1973.

Snyder, Jack. "International Leverage on Soviet Domestic Change." World Politics, Vol. 42 (1989), pp. 1-30.

Spring. Derek W. (ed.). The Impact of Gorbachev. The first phase, 1985-1990. London: Pinter, 1991.

Vincent, Jack E. "WEIS vs COPDAB: Correspondance Problems." International Studies Quarterly, Vol. 27 (1983), pp. 147-77.

Ward, Michael D. and Sheen Rajmaira. "Reciprocity and Norms in U.S. Soviet Foreign Policy." Journal of Conflict Resolution, Vol. 36 (1992), pp. 342-368.

Zisk, Kimberly Marten. Soviet Academic Theories on International Conflict and Negotiation: a Research Note. Journal of Conflict Resolution, Vol. 34 (1990), pp. 678-693. 